\title{
Productivity, Quality and Profitability of Dual Purpose Barley (Hordeum vulgare L.) Under Various Planting Techniques and Cutting Practices in Indo-Gangetic Plains of India
}

\author{
Manohar Lal ${ }^{*}$ and K.S. Saini \\ Department of Agronomy, Punjab Agricultural University, Ludhiana-141004, Punjab, India \\ *Corresponding author
}

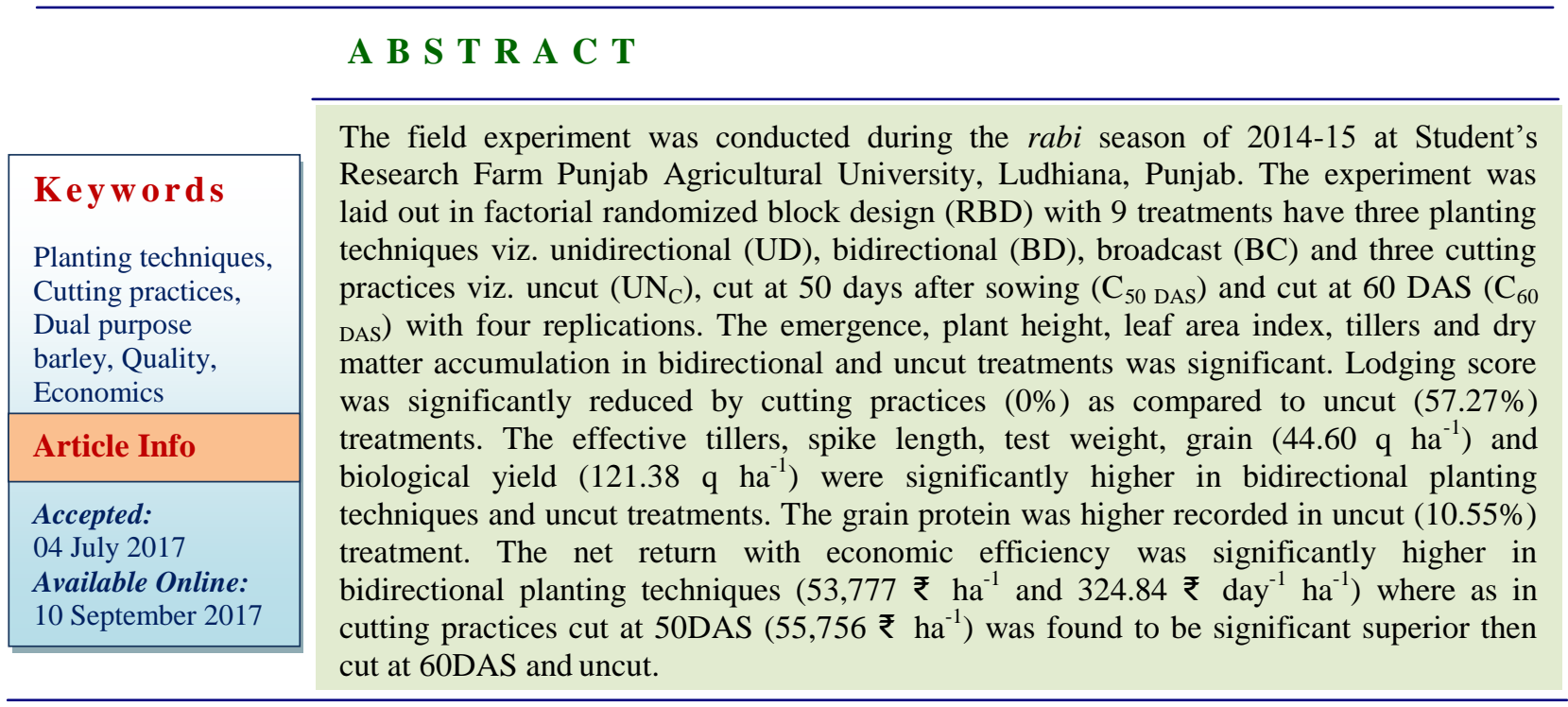

\section{Introduction}

Barley (Hordeum vulgare L.) is the fourth most important cereal crop of the world after wheat, rice and maize. India supports nearly 20 per cent of world's livestock being the leader in cattle (16\%) and buffalo $(5.5 \%)$ population. The livestock sector contributes 32 per cent for agricultural output, which is 22 per cent of total GDP in India. The shortage in green fodder and dry fodder animals is 21.8 per cent compared with requirement of 560 million tonnes (Kumar et $a l ., 2012)$. In India it is an important winter season cereal crop and major barley producing states Rajasthan, Uttar Pradesh,
Haryana, Madhya Pradesh, and Punjab. It is grown in our country in 0.63 million ha with a production of 1.20 million tonnes and an average productivity of 1.94 tonnes/ha (Anonymous, 2015). Barley grain has the largest use as animal feed all over the world and in India also a major share of barley grain is used as animal feed either alone or in combination. As a fodder crop, barley has tremendous potential and variation for production of very high amount of digestible dry matter as well as protein yield. Its grains contain 8 to 10 per cent protein and 74 per cent carbohydrates besides the minerals and 
vitamin B-complex and thus forms a staple food, cattle feed, malt for manufacturing of beer and other liquor products (Singh et al., 2009). Its straw is also used for making hay and silage. The barley produce from irrigated fertile areas is mainly used for industrial purposes, which accounts to nearly 20-25 per cent of the total production and the remaining quality from rainfed and less fertile area are utilized for cattle feed purpose (Sarkar et al., 2008). The studied in winter grain crops (wheat and barley) when sown in row of orientation East-West or North-South and observed that within wheat and barley crops oriented East-West, the grain yield increased by 24 and $26 \%$ as compared with crops oriented in North-South increase in crop yield likely resulted from the increased light interception (PAR) by crops oriented EastWest than compared to North-South sown crops (Catherine et al., 2010). The effect of cutting management practices on grain and fodder yield of barley at different stages of cutting (uncut, cut at 45 DAS, cut at 60 DAS and cut at 75 DAS). Uncut treatment significantly resulted the highest grains ${ }^{-1}$ and 1000-grain weight over rest of the cutting treatments.

However the differences between cutting at 45 and 60 days after sowing were found to be non-significant. The highest green fodder yield was obtained with cutting at 75 DAS, which was superior over cutting at 45 and 60 DAS (Singh et al., 2009). Different planting techniques (row orientation) and cutting management practices will influence the growth and yield of barely and their results will help to develop suitable agronomic practices to increase the productivity and profitability of barley. Keeping this in view, the present investigation was carried out to effect of different planting techniques and cutting practices of the productivity, quality and profitability of barley in indo-gangetic plains of India.

\section{Materials and Methods}

The field experiment was conducted during the rabi season of 2014-15 at Research Farm Punjab Agricultural University, Ludhiana, Punjab. The crop using variety PL 807 was on sown at $22.5 \mathrm{~cm}$ row spacing using $87.5 \mathrm{~kg}$ seed ha $^{-1}$ at Nov.5, 2014 of barley crop. The experiment was laid out in factorial randomized block design (RBD) with 9 treatments have three planting techniques viz. unidirectional (UD), bidirectional (BD), broadcast $(\mathrm{BC})$ and three cutting practices viz. uncut $\left(\mathrm{UN}_{\mathrm{C}}\right)$, cut at 50 DAS $\left(\mathrm{C}_{50}\right.$ DAS $)$ and cut at 60 DAS $\left(\mathrm{C}_{60} \mathrm{DAS}\right)$ with four replications. Statistical analysis by using STAR (Statistical Tool for Agricultural Research), software developed by Department of Plant Breeding Genetics and Biotechnology, IRRI (International Rice Research Institute), Manila, Phillipines based on the procedure of Cochran and Cox (1966).

The experimental field was collected before initiating the experiment and two $(0-15 \mathrm{~cm}$ and $15-30 \mathrm{~cm})$ composite sample was prepared. The field was moderately alkaline (8.3), electrical conductivity normal ( 0.40 and $0.30)$, low in organic carbon $(0.30$ and 0.18$)$ and low in available nitrogen $\left(130 \mathrm{~kg} \mathrm{ha}^{-1}\right)$, medium in available phosphorus (21.31 and $18.2 \mathrm{~kg} \mathrm{ha}^{-1}$ ) and potassium (185 and 156.2 $\mathrm{kg} \mathrm{ha}{ }^{-1}$ ) Havlin et al., (2014). Plant emergence in the marked area were recorded became constant completion of emergence were computed. Plant height of 10 tagged plants in the net plot was recorded. The numbers of tillers in the marked spots of half meter square area each plot were recorded. Dry matter accumulation in the above ground parts was recorded from half meter square area. The leaf area index with the help of leaf scanner and lodging score (0-10) of the crop was recorded by measure lodging crop area of crop in each plot than converted to per cent depending upon extend of lodging at harvest. 
Effective tillers were counted at maturity. The spike length of main ear on 10 tagged plants was measured from base of the tip floret excluding awns. During threshing 1000-grains sample was collected from each plot to present the data (Sardana and Zhang 2004). The net return and economic efficiency were calculated following formulas. Economic efficiency $\left(\right.$ day $\left.^{-1} \mathrm{ha}^{-1}\right)=$ Net return $\left(\mathrm{Cha}^{-1}\right) /$ Total duration taken crop (days) Rolaniya et al., (2015). Net returns $\left(\mathrm{ha}^{-1}\right)=$ the net returns were calculated by subtracting the cost of cultivation from the gross returns and presented as $\mathrm{ha}^{-1}$ (Sampath and Srinivas, 2017).

\section{Results and Discussion}

\section{Growth attributes}

The data presented in table 1 showed that the emergence count in BD technique statistically at par with UD technique, but significantly higher BC techniques for completion of emergence. The plant height at 90 and 120 DAS was significantly higher in BD technique and $\mathrm{UN}_{\mathrm{C}}$ treatment than other treatments of barley. Plant height was significantly higher when the wheat crop was raised with no cut as compared to the crop where one cut was imposed for taking additional forage yield (Kumar et al., 1999).

The LAI and tillers at 90 and 120 DAS in BD techniques was significantly higher than $\mathrm{BC}$ and UD planting techniques. However, BC and UD planting technique were at par. In cutting practices it was observed that the LAI at 90 DAS and 120 DAS of $U_{\mathrm{C}}$ treatment was significantly higher than $\mathrm{C}_{50}$ DAs and $\mathrm{C}_{60}$ DAS, but $\mathrm{C}_{50}$ DAS was significantly higher than $\mathrm{C}_{60}$ DAs of barley. The crop due to forage harvest, it might be the reason for higher LAI in $\mathrm{UN}_{\mathrm{C}}$ treatment. The higher LAI in bidirectional planting technique might be due to better canopy which intercepted more solar radiation and resulted better growth (Angiras and Sharma, 2016). The tillers count at 90 and 120 DAS $\mathrm{UN}_{\mathrm{C}}$ and $\mathrm{C}_{60}$ DAS were statistically at par, but significantly higher than $\mathrm{C}_{60}$ DAs of tillers. This might be due to longer vegetative growth period which resulted in more tillering and more number of tillers per unit area in uncut and cut 50 DAS (Dhillon and Kler, 1998). The dry matter accumulation at 90 and 120 DAS was significantly higher in bidirectional planting techniques compared to other treatments. At 90 and 120 DAS the dry matter accumulation by crop in $\mathrm{UN}_{\mathrm{C}}$ treatment was significantly higher than $\mathrm{C}_{50}$ DAS and $\mathrm{C}_{60}$ DAS.

\section{Grain protein and lodging score}

The data in table 1 indicate that the grain protein of barley was not influenced by planting techniques but significantly influenced by cutting practices. Protein content in grain was significantly higher in $\mathrm{UN}_{\mathrm{C}}$ treatment followed $\mathrm{C}_{50}$ DAS and $\mathrm{C}_{60}$ DAS. Lodging at harvest in bidirectional and broadcast planting techniques was statistically at par, but significantly higher than unidirectional planting techniques and cutting practices in $\mathrm{UN}_{\mathrm{C}}$ treatment was highest. Lodging may damage control 100 per cent by cutting practices at $\mathrm{C}_{50}$ DAS and $\mathrm{C}_{60}$ DAS. Lodging is due to the state of permanent displacement of the stems from their upright position. It is induced by external forces exerted by wind, rain, or hail and genetic characters of cultivar.

\section{Yield attributes}

The data presented in table 2 showed that BD gave significantly higher number of effective tillers and spike length than BC and UD, but $\mathrm{BC}$ and UD were statistically at par. The number of effective tillers and spike length in $\mathrm{UN}_{\mathrm{C}}$ and $\mathrm{C}_{50}$ DAS were statistically at par, but significantly higher than $\mathrm{C}_{60}$ DAs. Spike length 
might have reduced due to cutting treatment which would have decreased the photosynthetic assimilation from source to sink. Spike length might have reduced due to removal of vegetation which would have decreased the photosynthetic assimilation from source to sink. Thus, stress was imposed on the crop after forage harvest especially when cutting was done after 50 DAS of the crop. Similar results have been earlier reported by Das and Sarxas (2008) in which they observed that spike length in wheat was reduced in different varieties of wheat. The 1000-grain weight in $\mathrm{BD}$ techniques resulted higher test weight than $\mathrm{BC}$ and UD planting techniques, but broadcast and unidirectional planting techniques were at par. The test weight in $\mathrm{UN}_{\mathrm{C}}$ and $\mathrm{C}_{50}$ DAS were statistically at par, but significantly higher than $\mathrm{C}_{60}$ DAs. Sharma et al., (2001) also reported that in oats forage cutting at 65 DAS produced higher 1000grain weight than forage cutting at 80 DAS (Fig. 1).

Fig.1 Effect of planting techniques and cutting practices on grain yield $\left(\mathrm{q} \mathrm{ha}^{-1}\right)$, biological yield, net return ( $\left.₹ \mathrm{ha}^{-1}\right)$ and economic efficiency $\left(₹ \mathrm{day}^{-1} \mathrm{ha}^{-1}\right)$
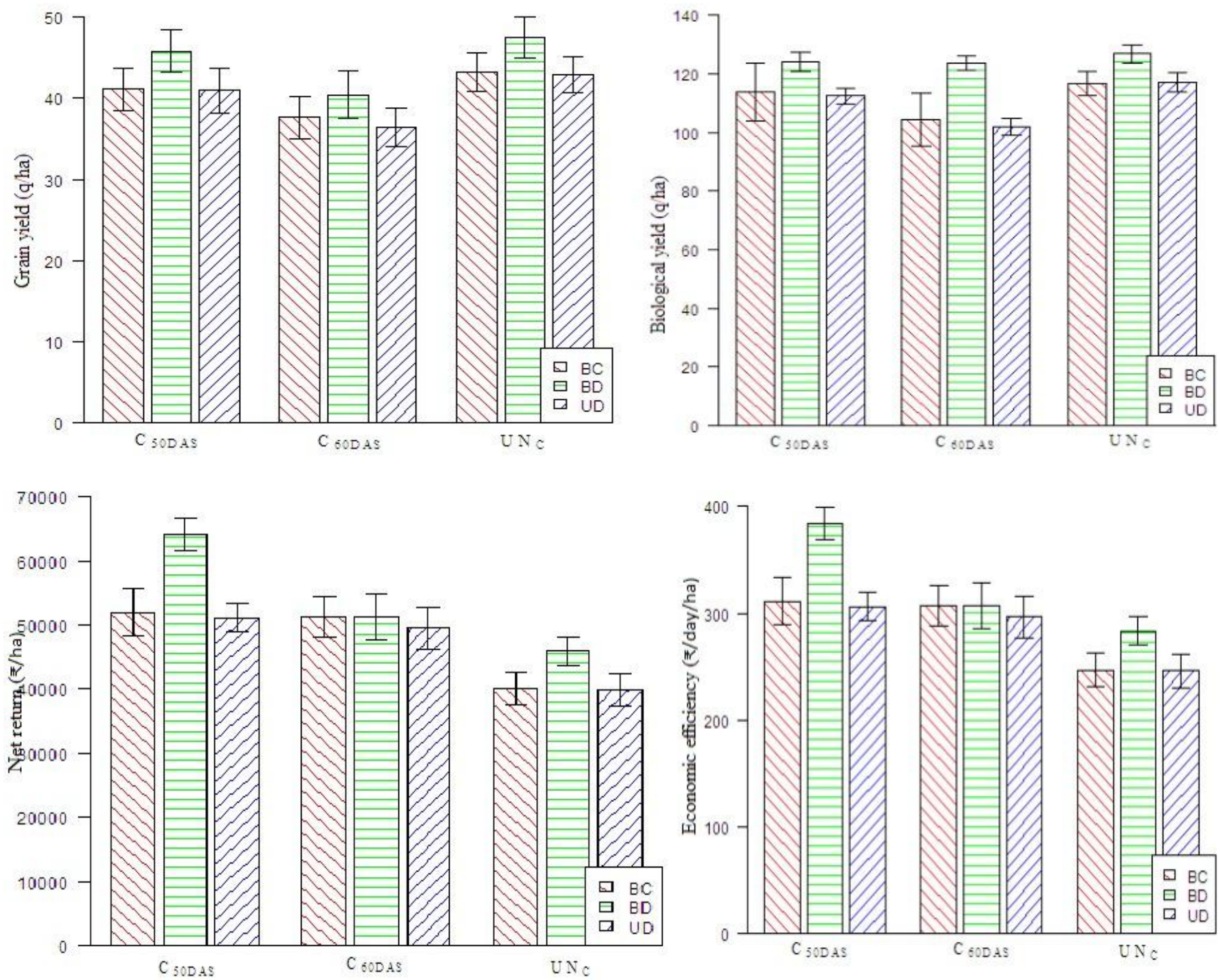
Table.1 Growth attributes, grain protein (\%) and lodging score (\%) as influenced by planting techniques and Cutting practices of barley

\begin{tabular}{|c|c|c|c|c|c|c|c|c|c|c|c|}
\hline \multirow[t]{2}{*}{ Treatment } & \multirow[t]{2}{*}{$\begin{array}{l}\text { Emergence } \\
\left(\mathrm{m}^{-2}\right) \text { 7DAS }\end{array}$} & \multicolumn{2}{|c|}{$\begin{array}{l}\text { Plant height } \\
(\mathrm{cm})\end{array}$} & \multicolumn{2}{|c|}{ LAI } & \multicolumn{2}{|c|}{$\begin{array}{l}\text { Tillers count } \\
\left(\text { No. } \mathrm{m}^{-2}\right)\end{array}$} & \multicolumn{2}{|c|}{$\begin{array}{l}\text { Dry matter } \\
\text { accumulation }\left(q \mathrm{ha}^{-1}\right)\end{array}$} & \multirow{2}{*}{$\begin{array}{l}\text { Grain } \\
\text { protein } \\
(\%)\end{array}$} & \multirow[t]{2}{*}{$\begin{array}{l}\text { Lodging } \\
\text { score }(\%)\end{array}$} \\
\hline & & $\begin{array}{c}90 \\
\text { DAS }\end{array}$ & $\begin{array}{c}120 \\
\text { DAS }\end{array}$ & 90 DAS & $\begin{array}{c}120 \\
\text { DAS } \\
\end{array}$ & $\begin{array}{c}90 \\
\text { DAS }\end{array}$ & $\begin{array}{c}120 \\
\text { DAS }\end{array}$ & 90 DAS & 120 DAS & & \\
\hline \multicolumn{12}{|c|}{ Planting techniques } \\
\hline Unidirectional & 376.00 & 49.98 & 81.39 & 3.16 & 4.22 & 421.37 & 396.19 & 24.89 & 96.80 & 9.93 & 14.82 \\
\hline Bidirectional & 376.83 & 61.98 & 92.22 & 3.55 & 4.78 & 461.16 & 431.19 & 27.90 & 108.60 & 10.39 & 21.67 \\
\hline Broadcast & 324.92 & 50.50 & 82.08 & 3.24 & 4.07 & 427.89 & 401.27 & 25.01 & 97.43 & 9.99 & 20.78 \\
\hline $\mathrm{CD}(\mathrm{P}=0.05)$ & 17.56 & 3.37 & 4.43 & 0.16 & 0.20 & 21.69 & 22.29 & 2.67 & 4.05 & $\mathrm{NS}$ & 1.83 \\
\hline \multicolumn{12}{|c|}{ Cutting practices } \\
\hline Un-cut & 359.0 & 81.60 & 95.01 & 4.79 & 5.23 & 461.74 & 435.91 & 41.78 & 118.49 & 10.55 & 57.27 \\
\hline Cut at $50 \mathrm{DAS}$ & 359.50 & 46.24 & 86.78 & 2.84 & 4.37 & 448.60 & 420.94 & 27.33 & 106.22 & 10.12 & 0 \\
\hline Cut at 60 DAS & 359.25 & 34.62 & 73.89 & 2.31 & 3.46 & 400.07 & 371.75 & 8.70 & 77.58 & 9.64 & 0 \\
\hline $\mathrm{CD}(\mathrm{P}=0.05)$ & $\mathrm{NS}$ & 3.37 & 4.43 & 0.16 & 0.20 & 21.69 & 22.29 & 2.67 & 4.05 & 0.41 & 1.83 \\
\hline Interaction & NS & 5.81 & $\mathrm{NS}$ & NS & NS & $\mathrm{NS}$ & $\mathrm{NS}$ & NS & NS & $\mathrm{NS}$ & 3.16 \\
\hline
\end{tabular}

Table.2 Yield parameters, yield and economics as influenced by planting techniques and cutting practices of barley

\begin{tabular}{|c|c|c|c|c|c|c|c|c|c|}
\hline Treatment & $\begin{array}{c}\text { Effective } \\
\text { tillers } \\
\left(\text { no. } \mathbf{m}^{-2}\right) \\
\end{array}$ & $\begin{array}{c}\text { Spike } \\
\text { length } \\
(\mathrm{cm})\end{array}$ & $\begin{array}{l}\text { 1000-grain } \\
\text { weight } \\
\text { (g) }\end{array}$ & $\begin{array}{c}\text { Grain yield } \\
\left(\mathbf{q} \mathrm{ha}^{-1}\right)\end{array}$ & $\begin{array}{c}\text { Biological } \\
\text { yield (q ha } \\
\left.{ }_{1}\right)\end{array}$ & $\begin{array}{c}\text { Harvest } \\
\text { index } \\
(\%)\end{array}$ & $\begin{array}{l}\text { Gross } \\
\text { expenditure } \\
\left(₹ \text { ha }^{-1}\right)\end{array}$ & $\begin{array}{l}\text { Net return } \\
\left(₹ \text { ha }^{-1}\right)\end{array}$ & $\begin{array}{c}\text { Economic } \\
\text { efficiency (₹ } \\
\text { day }^{-1} \mathrm{ha}^{-1} \text { ) }\end{array}$ \\
\hline \multicolumn{10}{|c|}{ Planting techniques } \\
\hline Bidirectional & 396.04 & 7.63 & 38.87 & 44.60 & 121.38 & 36.82 & 22,214 & 53,777 & 324.84 \\
\hline Broadcast & 356.34 & 6.97 & 36.88 & 40.65 & 111.65 & 36.46 & 22,214 & 47,779 & 288.56 \\
\hline $\mathrm{CD}(\mathrm{P}=0.05)$ & 19.59 & 0.38 & 1.62 & 2.141 & 3.797 & NS & - & 2417 & 14.57 \\
\hline Cut at 50 DAS & 379.37 & 7.27 & 38.45 & 42.64 & 116.82 & 36.62 & 22,622 & 55,756 & 333.85 \\
\hline Cut at 60 DAS & 324.05 & 6.45 & 34.38 & 38.16 & 106.48 & 35.92 & 22,622 & 50,710 & 303.65 \\
\hline $\mathrm{CD}(\mathrm{P}=0.05)$ & 19.59 & 0.38 & 1.62 & 2.141 & 3.797 & NS & - & 2417 & 14.57 \\
\hline Interaction & NS & NS & NS & NS & NS & NS & - & 4161 & 25.08 \\
\hline
\end{tabular}


Table.3 Interaction effect of different planting techniques and Cutting practices on economics in barley

\begin{tabular}{lcccccc}
\hline \multicolumn{1}{c}{$\begin{array}{c}\text { Cutting } \\
\text { practices }\end{array}$} & \multicolumn{3}{c}{ Net return $\left(₹ \mathbf{~ h a}^{-1}\right)$} & \multicolumn{2}{c}{ Economic efficiency $\left(₹\right.$ day $\left.^{-1} \mathbf{h a}^{-1}\right)$} \\
\cline { 2 - 7 } $\begin{array}{l}\text { Planting } \\
\text { techniques }\end{array}$ & Un-cut & $\begin{array}{c}\text { Cut at 50 } \\
\text { DAS }\end{array}$ & $\begin{array}{c}\text { Cut at } \\
\text { 60 DAS }\end{array}$ & Un-cut & $\begin{array}{c}\text { Cut at 50 } \\
\text { DAS }\end{array}$ & $\begin{array}{c}\text { Cut at 60 } \\
\text { DAS }\end{array}$ \\
\hline Unidirectional & 39,841 & 51,152 & 49,518 & 245.90 & 306.27 & 296.50 \\
Bidirectional & 45,923 & 64,108 & 51,310 & 283.45 & 383.87 & 307.27 \\
Broadcast & 40,018 & 52,008 & 51,300 & 247.02 & 311.40 & 307.20 \\
CD (P=0.05) & & 4161 & & & 25.08 & \\
\hline
\end{tabular}

\section{Yield and Economics}

The data presents in table 2 showed that the grain and biological yield varied significantly, $\mathrm{BD}$ techniques produced the higher grain and biological yield than $\mathrm{BC}$ and $\mathrm{BD}$ techniques, but broadcast and unidirectional were planting techniques statistically at par. Vaishya and Singh (2009) reported higher grain yield in cross-planting at $22.5 \mathrm{~cm}$. The results were in line with the findings of Ketata et al., (2011) in which they reported that bidirectional planting for sowing of wheat significantly increased yield of winter wheat. The grain and biological yield in $\mathrm{UN}_{\mathrm{C}}$ and $\mathrm{C}_{50}$ DAS were statistically at par, but significantly higher than $\mathrm{C}_{60}$ DAs. The similar results reported by Ram et al., 2012.

The grain yield reduction might be due to shortening of vegetative and reproductive period. The yield components, reduced by clipping, were the most important contribution to loss of grain yield (El-Shatnawi and Haddad, 2004). The different planting techniques of barley viz. bidirectional, broadcast and unidirectional and cutting practices did not affect the harvest index. Interaction effect of planting techniques and cutting practices was found to be non-significant. The highest net return and economic efficiency in bidirectional planting technique were significantly better than other treatments, while it was least under unidirectional planting. In cutting practices highest net return $\mathrm{C}_{50}$ DAs followed by $\mathrm{C}_{60}$ DAS and $\mathrm{UN}_{\mathrm{C}}$ treatment lowest net return. The effect of cutting management of oats for forage gave higher net returns, which are in line with the present findings interaction effect of different planting techniques and cutting practices on the economics of barley crop were found to be significant (Singh et al., 2008).

\section{Interaction effect}

\section{Economics}

The data in the table 3 indicated that bidirectional planting technique $\mathrm{C}_{50}$ DAs fetched the highest net return (₹ 64,108 ha ${ }^{-1}$ ) with economic efficiency (383.87 ₹ day $\left.^{-1} \mathrm{ha}^{-1}\right)$, while it was followed to be least under $\mathrm{UN}_{\mathrm{C}}$ (grain yield) unidirectional planting techniques (₹ $39,841 \mathrm{ha}^{-1}$ ) with economic efficiency (245.90 ₹ day $\left.^{-1} \mathrm{ha}^{-1}\right)$.

\section{Acknowledgement}

The first author is thankful to Department of Agronomy, Punjab Agricultural University, Ludhiana for providing field and lab facilities to conduct this experiment. Author is also thankful to the anonymous reviewer/referee for the valuable suggestions and comments to improve the paper.

\section{References}

Angiras, N., and Sharma, V. 2016. Influence of row orientation, row spacing and weed control methods on physiological performance of irrigated wheat (Triticum aestivum L.). Indian J Agron 41 (3): 4147.

Anonymous, 2015. The barley state production 
in India. http://www.indistat.com.

Catherine, P.D., Borger, Hashem. A and Pathan, S. 2010. Manipulating crop row orientation to suppress weeds and increase crop yield. Weed Sci, 58: 174-78.

Cochran, W.G., and Cox, G.M. 1967. Experiment Designs. Asia publishing House, New Delhi, India.

Das, N.R., and Sarxas, S. R. 2008. Effect of variety and fertility level on yield of dwarf wheat in West Bengal. Enviro and Ecol., 6 (1): 103-106.

Dhillon, G.S., and Kler, D. S. 1998. Preliminary studies on source-sink relationship in wheat. Indian Agron., 21 (1): 92-94.

El-Shatnawi, M.K.J., and Haddad, N. I. 2004. Assessing barley (Hordeum vulgare L.) response to clipping in the semi-arid Mediterranean Climate. Aust $J$ Expt Agric., 44 (1): 34-42.

Hales, D., 1992. Eat smart, feed good and look great. Readers Digest (New York) 8:63.

Havlin, J.L., Tisdale, S. L., Nelson, W.L and Beaton, J. D. 2014. Soil fertility and fertilizers. PHI Learning Private limited, Delhi, India

Ketata, H., Edwards, L. H and Morrison, R. D. 2011. Response of three hard red winter wheat cultivars to four planting arrangements. Agron J., 68: 428-29.

Kumar, A., Arya, R. K., Kumar, S., Kumar, D., Kumar, S and Panchata, R. 2012. Effect of cultivars and plant geometry on dry fodder production on barley under various moisture regimes on raised bed planting. Forage Res 38: 1-14.

Kumar, S., Badiyala, D., Singh, C. M and Saroch, K. 1999. Nitrogen and cutting management in winter wheat (Triticum aestivum L.) under dry temperate high hills. Indian J. Agron., 44(3): 112-14.

Ram, H., Kumar, B., Chuadhary, D. P and Bakshi, M. P. S. 2012. Productivity, quality and economics of dual purpose barley (Hordeum vulgare L.) varieties under different nitrogen scheduling. Vegetos, 25(1): 68-70.

Rolaniya, L. K., Dwivedi, A., Vivek, Punia, M., Humphreys, E and Mishra, A. 2015. Effect of irrigation scheduling and weed management on weed dynamics, water productivity and performance of dry seeded rice. Green Farming., 6: 1-6

Sampath, O., and Srinivas, A. 2017. Economics of Rice Varieties as Influenced by Combination of Plant Densities and Fertilizer Levels under Late Sown Conditions.

Int.J.Curr.Microbiol.App.Sci., 6(7): 17-21

Sardana, V., and Zhang, G.P. 2004. Effect of time of $\mathrm{N}$ application of growth and yield of barley (Hordeum vulgare L.) cultivars. Cereal Res Comm., 103: 1.

Sarkar, B., Verma, R. P. S and Mishra, B. 2008. Association of important malting traits in barley (Hordeum vulgare L.). Indian $J$ Agron., 51 (1): 40-42.

Sharma, S.K., and Bhunia, S. R. 2001. Response of oats to cutting management, method of sowing and nitrogen. Indian $J$ Agron., 46(3): 563-67

Singh, R., Sood, B. R., Sharma, U. K and Rana, N. S. 2008. Effect of cutting management and nitrogen on forage and seed yields of oats (Avena sativa L.). Indian J Agron., 43(2): 362-66.

Singh, R.P., Tripathi, H. P and Yadav, A. S. 2009. Effect of storage of cutting and nitrogen levels on grain and fodder yield of barley (Hordeum vulgare L.). Indian J Agric Sci., 79: 78-79.

Vaishya, R.D., and Singh, V. 2009. Effect of seed rate, row spacing and $\mathrm{N}$ on yield and uptake of $\mathrm{N}$ in late sown wheat. Indian $J$ Agron., 26 (1): 53-58.

\section{How to cite this article:}

Manohar Lal and Saini, K.S. 2017. Productivity, Quality and Profitability of Dual Purpose Barley (Hordeum vulgare L.) Under Various Planting Techniques and Cutting Practices in Indo-Gangetic Plains of India. Int.J.Curr.Microbiol.App.Sci. 6(9): 648-654. doi: https://doi.org/10.20546/ijcmas.2017.609.080 